\title{
Components of a Rice-Oilseed Rape Production System Augmented with Trichoderma sp. Tri-1 Control Sclerotinia sclerotiorum on Oilseed Rape
}

\author{
Xiaojia Hu, Daniel P. Roberts, Lihua Xie, Jude E. Maul, Changbing Yu, Yinshui Li, Yinbo Zhang, Lu Qin, and Xing Liao \\ First, third, fifth, sixth, seventh, eighth, and ninth authors: Key Laboratory of Biology and Genetic Improvement of Oil Crops, Ministry of \\ Agriculture, Oil Crops Research Institute, Chinese Academy of Agricultural Sciences, Wuhan, 430062, People's Republic of China; and \\ second and fourth authors: Sustainable Agricultural Systems Laboratory, U.S. Department of Agriculture-Agricultural Research Service, \\ Beltsville, MD 20705-2350.
}

Accepted for publication 18 May 2015.

\begin{abstract}
Hu, X., Roberts, D. P., Xie, L., Maul, J. E., Yu, C., Li, Y., Zhang, Y., Qin, L., and Liao, X. 2015. Components of a rice-oilseed rape production system augmented with Trichoderma sp. Tri-1 control Sclerotinia sclerotiorum on oilseed rape. Phytopathology 105:1325-1333.

Sclerotinia sclerotiorum causes serious yield losses on many crops throughout the world. A multicomponent treatment that consisted of the residual rice straw remaining after rice harvest and Trichoderma sp. Tri-1 (Tri-1) formulated with the oilseed rape seedcake fertilizer was used in field soil infested with S. sclerotiorum. This treatment resulted in oilseed rape seed yield that was significantly greater than the nontreated control or when the fungicide carbendizem was used in the presence of this pathogen in field trials. Yield data suggested that the rice straw, oilseed rape seedcake, and Tri-1 components of this treatment all contributed

incrementally. Similar treatment results were obtained regarding reduction in disease incidence. Slight improvements in yield and disease incidence were detected when this multicomponent treatment was combined with a fungicide spray. Inhibition of sclerotial germination by this multicomponent treatment trended greater than the nontreated control at 90,120, and 150 days in field studies but was not significantly different from this control. This multicomponent treatment resulted in increased yield relative to the nontreated control in the absence of pathogen in a greenhouse pot study, while the straw alone and the straw plus oilseed rape seedcake treatments did not; suggesting that Tri- 1 was capable of promoting growth. Experiments reported here indicate that a treatment containing components of a rice-oilseed rape production system augmented with Tri- 1 can control S. sclerotiorum on oilseed rape, be used in integrated strategies containing fungicide sprays for control of this pathogen, and promote plant growth.
\end{abstract}

Sclerotinia sclerotiorum (Lib.) de Bary is a widespread pathogen causing diseases on over 400 plant species from at least 75 families worldwide including many important crops (Boland and Hall 1994). This pathogen causes the economically important disease Sclerotinia stem rot of oilseed rape or canola in the People's Republic of China and other regions of the world (Martens et al. 1994; Purdy 1979; Zhao and Meng 2003). Oilseed rape is the major oilseed crop in China with approximately $7 \times 10^{6}$ ha in production (Guan 2011). Yield losses due to this disease vary from year to year but can range from 10 to $80 \%$ of the crop (Ma et al. 2009b). Decreases in oil quality may also result (Ma et al. 2009b). S. sclerotiorum overwinters as sclerotia in soil which, upon germination, produce apothecia or directly produce mycelia. Ascospores released from apothecia are the primary inoculum for most diseases of S. sclerotiorum and require senescing or dead tissue of the host for germination and saprophytic colonization (Abawi and Grogan 1979; Boland 2004). These ascospores generally germinate on senescing flower petals on oilseed rape (Turkington and Morrall 1993) and infection of healthy foliar tissues follows (Abawi and Grogan 1979; Boland 2004). Mycelia produced directly from germinating sclerotia can also infect the plant at the soil line.

Application of fungicides is the primary method for control of diseases caused by this pathogen (Bardin and Huang 2001; Lu 2003; Ma et al. 2009b; Yu and Zhou 1994). Several fungicides are available, but these chemicals are expensive and there are concerns

Corresponding authors: D. P. Roberts; E-mail address: dan.roberts@ ars.usda.gov X. Liao; E-mail address: liaox@ oilcrops.cn

http://dx.doi.org/10.1094/PHYTO-12-14-0371-R

This article is in the public domain and not copyrightable. It may be freely reprinted with customary crediting of the source. The American Phytopathological Society, 2015 regarding their use as they are hazardous both to humans and the environment (Fernando et al. 2007; Lu 2003). Additionally, the fungicides carbendizem and dimethaclon, used to control this disease in China and elsewhere are becoming ineffective due to the development of fungicide resistance in populations of $S$. sclerotiorum (Ma et al. 2009a; 2009b; Wang et al. 2015; Yin et al. 2010). Control tactics such as crop rotation and breeding for resistance to this disease have met with limited success (Bardin and Huang 2001; Turkington and Morrall 1993). Crop rotation can be ineffective due to the wide host range of S. sclerotiorum and the lengthy persistence of sclerotial survival structures in soil (Nelson 1998). For example, a 3- to 4-year rotation did not reduce incidence of disease on canola (Morrall and Dueck 1982; Williams and Stelfox 1980). Traditional oilseed rape breeding programs for disease resistance have been hampered by a limited gene pool, the fact that resistance is governed by multiple genes, and the tendency to select oilseed rape cultivars with low seed glucosinolate content (Bardin and Huang 2001; Fuller et al. 1984; Lu 2003). It is clear that safe, environmentally compatible, and economically feasible disease management tactics are needed for controlling S. sclerotiorum on crops such as oilseed rape.

Biological control of $S$. sclerotiorum has received considerable attention due to its potential to provide safe and environmentally compatible disease control (Fernando et al. 2004; Fravel 1998; Hu et al. 2011; Zhou and Boland 1998). However, acceptance of commercial biological control products by growers has been slowed by their inconsistent performance (Fravel 2005; Glare et al. 2012). Approaches to overcoming inconsistent performance by biological control agents include the integration of multiple microbes into individual biological control formulations (Lemanceau and Alabouvette 1991; Pierson and Weller 1994; Raupach and Kloepper 1998) and the use of multiple methods of applying microbial biological control agents (Ji et al. 2006; Wilson 1996; 1997). Our long-term goal is to develop a sustainable 
disease control strategy for S. sclerotiorum on oilseed rape based on a combination of these approaches, where various biological control agents are applied using multiple application strategies targeting different aspects of the disease cycle.

We have isolated three Bacillus strains that provide control of S. sclerotiorum on oilseed rape in the field, control which is comparable to that provided by a chemical pesticide when applied as seed treatment formulations or as a spray at flowering (Hu et al. 2011; 2013a; 2014). These Bacillus strains control S. sclerotiorum on oilseed rape by protecting the plant from infection, although the exact mechanisms by which they control this disease are unknown. Here we target another portion of the disease cycle, the sclerotia of S. sclerotiorum, with a mycoparasitic isolate of Trichoderma (Hu et al. 2013c). Use of mycoparasites to kill or weaken sclerotia and thereby reduce initial inoculum is an often used strategy for biological control of Sclerotinia spp. (Zhou and Boland 1998). In addition, certain isolates of Trichoderma are also known to stimulate plant growth in the absence of pathogens (Harman et al. 2004; Howell 2003). Using a rice-oilseed rape rotation prevalent in China the major objectives of this study were to (i) determine control of $S$. sclerotiorum using a multicomponent treatment consisting of the oilseed rape seedcake fertilizer and rice straw components of this production system augmented with Trichoderma sp. Tri-1 (Tri-1) cultivated into the soil prior to sowing this crop, (ii) determine the impact of this multicomponent treatment on germination of sclerotia of this pathogen, and (iii) determine plant growth promotion by this treatment. Another objective of this study was to determine if this multicomponent treatment containing Tri-1 enhanced degradation of rice straw remaining in the field after rice harvest.

\section{MATERIALS AND METHODS}

Fungal isolates. Trichoderma sp. Tri-1 (Tri-1) was isolated from the rhizosphere of an oilseed rape root (Brassica napus L. 'Zhongshuang 9') from a research plot at the Oil Crops Research Institute, Wuhan, People's Republic of China. This isolate was shown to decompose rice straw and infect sclerotia of S. sclerotiorum (Hu et al. 2010). Unless indicated otherwise, isolate Tri-1 was cultured in potato dextrose broth (PDB) or potato dextrose agar (PDA) plus hygromycin $(50 \mu \mathrm{g} / \mathrm{ml})$ as this isolate was naturally resistant to that level of hygromycin. Isolate Tri-1 was stored long term in $20 \%$ glycerol at $-70^{\circ} \mathrm{C}$. S. sclerotiorum Ss-1 was isolated from a sclerotium formed on oilseed rape (Hu et al. 2005). Isolate Ss- 1 was maintained on PDA at 20 to $22^{\circ} \mathrm{C}$. All microorganisms were obtained from the culture collection of the Plant Protection Laboratory, Oil Crops Research Institute, Wuhan. Isolate Tri-1 is also held in the Agricultural Culture Collection of China (Beijing) as ACCC 32501 and S. sclerotiorum Ss-1 is held as ACCC 36169.

Preparation of formulated Tri-1. Formulated Tri-1 was prepared as previously described (Min 2008). Briefly, a mixture (500 g) containing 50\% oilseed rape seedcake (Wuhan Zhongyou Kangni Technology Co., Ltd., Wuhan), $20 \%$ rice straw (rice straw was removed from an experimental field after grain harvest, dried at $70^{\circ} \mathrm{C}$, ground, and passed through a 10 mesh sieve prior to use), and $30 \%$ water (wt/wt/vol) was autoclaved at $121^{\circ} \mathrm{C}$ for $30 \mathrm{~min}$ in a covered 1 liter beaker. The mixture was then inoculated with $2 \mathrm{ml}$ of Tri- 1 spore suspension containing $\geq 10^{4}$ spores $/ \mathrm{ml}$. Tri- 1 was grown on PDA for 5 days at $28^{\circ} \mathrm{C}$, and a conidial suspension was prepared by washing plates with an aqueous solution containing $0.9 \% \mathrm{NaCl}$. The Tri-1 formulation was incubated at $25^{\circ} \mathrm{C}$ for 8 days with mixing every 2 days. The Tri- 1 formulation was then air dried at $25^{\circ} \mathrm{C}$ in petri dishes for 7 days. The noninoculated formulation treatment consisted of the oilseed rape seedcake plus straw mixture formulation prepared as above but not inoculated with Tri-1.

Field trials. Field experiments were conducted from October through May in each of two subsequent years in Wuxue County, Hubei Province, China as described (Hu et al. 2011; 2013a; 2014) at different field sites within the same research center. The fields contained a clay loam soil $(\mathrm{P}, 6.5 \mathrm{mg} / \mathrm{kg} ; \mathrm{N}, 117.0 \mathrm{mg} / \mathrm{kg} ; \mathrm{K}$, $236.2 \mathrm{mg} / \mathrm{kg}$; organic matter, $1.91 \% ; \mathrm{pH} 7.0)$ and sclerotia of S. sclerotiorum Ss-1 remaining from prior field trials. Six blocks were arranged in a random complete block design surrounded by a 1-meter-wide protective belt of oilseed rape plants. Each replicate treatment plot in each block was $3.3 \mathrm{~m} \times 2 \mathrm{~m}$ with 10 rows planted at a density of 10 seeds $/ \mathrm{m}$ and rows spaced $33 \mathrm{~cm}$ apart. There were eight treatments. The first four treatments were as follows: (i) no treatment, (ii) rice straw alone, (iii) rice straw plus formulated Tri-1 (containing $2 \times 10^{8} \mathrm{CFU} / \mathrm{g}$ of Tri-1), and (iv) rice straw plus noninoculated formulation. These treatments had fertilizer (per plot: urea, $230 \mathrm{~g}$; superphosphate, $330 \mathrm{~g}$; potassium chloride, $100 \mathrm{~g}$; and borax, $5 \mathrm{~g}$ ) cultivated into the soil prior to sowing oilseed rape seed. An additional $109 \mathrm{~g}$ of urea/plot was applied as a top dressing in early January as recommended for this region of China (Su et al. 2011). Treatment $i$ had no additional amendments. For treatment ii, $2.0 \mathrm{~kg}$ of rice straw/plot (rice straw was removed from an experimental field after grain harvest, dried at $70^{\circ} \mathrm{C}$, and chopped into 8 to $10 \mathrm{~cm}$ segments) was cultivated into the soil along with the fertilizer just prior to sowing oilseed rape seed. Treatment iii was the same as treatment ii, except $100 \mathrm{~g}$ of formulated Tri-1/plot was cultivated into the soil along with the straw and fertilizer. Treatment iv was the same as treatment iii except the noninoculated formulation was used. The remaining four treatments (v, vi, vii, and viii) were the same as treatments i to iv, except carbendizem $(2.0 \mathrm{~g}$ [ $25 \%$ a.i., $75 \%$ inert material] in $500 \mathrm{ml}$ of tap water, approximately $4.0 \mathrm{ml}$ applied to each plant) was applied as a spray when approximately $70 \%$ of the plants were at flowering. Carbendazim was the fungicide standard control and was applied at the recommended rate for oilseed rape in this region of China. Three replicate plots for each treatment were used to determine impact of these treatments on disease incidence, yield, germination of sclerotia of S. sclerotiorum, and straw decomposition as described below in this section.

At the seven-leaf stage, rows were thinned to 12 plants/row. Five days prior to harvest, 120 plants from each replicate plot were rated for disease incidence ( $\mathrm{Li}$ et al. 2007). An oilseed rape plant was considered diseased if one third of the branches on the plant contained one or more lesions resulting from infection by S. sclerotiorum or if the plant contained a lesion on the caulis (Zhou 1994). S. sclerotiorum was isolated from diseased tissue from random samples to confirm that disease was caused by this pathogen. Mean disease incidence was determined for each treatment replicate, subjected to analysis of variance (ANOVA), and differences among means estimated using least significant difference (LSD) in Proc GLM in SAS ver. 9.3 (SAS Institute, Cary, NC). Disease incidence data from the two field experiments were combined prior to analysis $(n=2)$ as there was no significant experiment $\times$ treatment effect $(P=0.9802)$.

Yield was determined at harvest by sampling 120 plants in each replicate plot for seed dry weight. Seed were weighed after drying in the sun for 2 days. Mean yield per 120 plants was determined, subjected to ANOVA, and differences among means estimated using LSD in Proc GLM in SAS. Yield data from the two field experiments were combined prior to analysis $(n=2)$ as there was no significant experiment $\times$ treatment effect $(P=0.9671)$.

For determination of sclerotial germination, three nylon mesh bags $(5 \times 5 \mathrm{~cm})$ per replicate plot, each containing 21 sclerotia, were buried at a depth of $2 \mathrm{~cm}$ and marked with a stake immediately prior to sowing oilseed rape seeds. Sclerotia were collected from infected plants the prior May, dried at 25 to $28^{\circ} \mathrm{C}$ for 2 days, and stored in a desiccation chamber at 25 to $28^{\circ} \mathrm{C}$ until used. One mesh bag was removed from each replicate plot at each of the following time points: 90, 120, and 150 days. The sclerotia were washed, surface sterilized by soaking in $0.1 \% \mathrm{HgCl}_{2}$ for $2 \mathrm{~min}$, rinsed seven times in sterile water, and germination determined by incubation on PDA for $72 \mathrm{~h}$ at $22^{\circ} \mathrm{C}$. The number of germinated sclerotia in each bag were 
modeled using an overdispersed binomial treatment $\times$ days ANOVA with logit link function. Pairwise means comparisons were made on the percent germinated sclerotia for each treatment $\times$ days, using the ilink option (Stroup 2013) in Proc GLIMMIX in SAS. No experiment effects were significant $(P=0.4630)$ in an experiment $\times$ treatment $x$ days fixed-effects ANOVA using bags within experiment $x$ treatment $\times$ days as the error term, so data from the two experiments were combined $(n=2)$.

Straw decomposition was determined after 150 days. Three samples $\left(0.36 \mathrm{~m}^{2} \times 20 \mathrm{~cm}\right.$ deep $)$ were taken from each of three replicate plots per treatment. The undecomposed rice straw was removed from each sample, washed with sterile water, dried at $80^{\circ} \mathrm{C}$ for $12 \mathrm{~h}$, and weighed. Mean residual straw $(\mathrm{g}) / 0.072 \mathrm{~m}^{3}$ was determined, subjected to ANOVA, and differences among means estimated using LSD in Proc GLM in SAS. Data from the two field experiments were combined prior to analysis $(n=2)$ as there were no significant experiment $\times$ treatment effect $(P=0.3119)$.

The remaining three replicate plots for each treatment in each experiment were used to determine the impact of these treatments on soil available $\mathrm{N}, \mathrm{P}$, and $\mathrm{K}$; soil organic matter; and soil acid phosphatase, invertase, and urease activities as described below.

Soil acid phosphatase, invertase, and urease activities in field experiments. For determination of soil acid phosphatase, invertase, and urease activities in the field experiments, $100 \mathrm{~g}$ of soil was removed from each of three replicate plots for each treatment at 150 days, passed through a 100 mesh sieve, and used directly in enzyme assays. Soil moisture was $23.5 \%$. Acid phosphatase activity was determined using the method of Tabatabai and Bremner (1969) where one unit of acid phosphatase activity was defined as the amount of enzyme that released $1 \mu \mathrm{g}$ of $p$-nitrophenol equivalents $/ \mathrm{h} / \mathrm{g}$ of soil (Hu et al. 2013b). Soil invertase activity was determined using the 3,5-dinitrosalicylic acid method of Schinner and von Mersi (1990). One unit of soil invertase activity was defined as the amount of enzyme that released $1 \mathrm{mg}$ of glucose equivalents/g of soil/day. Soil urease activity was measured by incubating soil in a buffered urea solution, extraction of ammonia with $\mathrm{KCl}$ and $\mathrm{HCl}$, followed by colorimetric ammonia determination using a modified indophenol reaction (Kandeler and Gerber 1988). One unit of urease activity was defined as the amount of enzyme that produced $1 \mathrm{mg}$ of ammonia/g of soil/day. Mean unit acid phosphatase, invertase, and urease activity were determined, subjected to ANOVA, and differences among means estimated using LSD in Proc GLM in SAS. Data from the two field experiments for acid phosphatase $(P=0.8080, n=2)$, invertase $(P=0.8554, n=2)$, and urease $(P=0.6763, n=2)$ activities were combined prior to analysis as there were no significant experiment $x$ treatment effects.

Determination of soil available $N, P$, and $K$ and soil organic matter in field experiments. For the field experiments, $100 \mathrm{~g}$ of soil was removed from each of three replicate plots for each treatment at 150 days, dried at room temperature for 7 days, and passed through a 100 mesh sieve. Soil available N was determined using the Kjelhdal method, soil available P using the method of Olson, soil available K by flame photometry, and soil organic matter using the difference in soil weight before and after combustion (Bao 2000; Olsen et al. 1954). Mean available $\mathrm{mg}$ of $\mathrm{N} / \mathrm{kg}$ of soil, mean $\mathrm{mg}$ of $\mathrm{P} / \mathrm{kg}$ of soil, mean $\mathrm{mg}$ of $\mathrm{K} / \mathrm{kg}$ of soil, and mean $\mathrm{g}$ of organic matter $/ \mathrm{kg}$ of soil were determined, subjected to ANOVA, and differences among means estimated using LSD in Proc GLM in SAS. Data for the two field experiments for mean available $\mathrm{mg}$ of $\mathrm{N} / \mathrm{kg}$ of soil $(P=0.9448)$, mean $\mathrm{mg}$ of $\mathrm{P} / \mathrm{kg}$ of soil $(P=0.8905)$, mean $\mathrm{mg}$ of $\mathrm{K} / \mathrm{kg}$ of soil $(P=0.9919)$, and mean $\mathrm{g}$ of organic matter/kg of soil $(P=0.8734)$ were combined $(n=2)$ as there were no significant experiment $\times$ treatment effects.

Greenhouse plant growth promotion pot experiments. Pots $(20 \mathrm{~cm}$ height $\times 21 \mathrm{~cm}$ diameter) were filled with $5 \mathrm{~kg}$ of sieved (20 mesh sieve), dried soil (calcareous Chao soil that was collected from the top $10 \mathrm{~cm}$ of a research plot and had the following characteristics: alkali-hydrolyzable N, $96.2 \mathrm{mg} / \mathrm{kg}$; available P,
$14.3 \mathrm{mg} / \mathrm{kg}$; available $\mathrm{K}, 127.5 \mathrm{mg} / \mathrm{kg}$; organic matter $1.4 \%$; $\mathrm{pH}$ 6.9). The following treatments were applied to pots: (i) no treatment, (ii) rice straw alone, (iii) rice straw plus formulated Tri-1 (containing $2 \times 10^{8} \mathrm{CFU} / \mathrm{g}$ of Tri-1), and (iv) rice straw plus noninoculated formulation. Fertilizer and treatments were mixed into the soil prior to adding soil to the pots. Rice straw was applied at the rate of $103.8 \mathrm{~g} / \mathrm{pot}$ and formulated Tri-1 or the noninoculated formulation at $5.2 \mathrm{~g} /$ pot. Chemical fertilizer (urea, $1.4 \mathrm{~g}$; $\mathrm{Ca}\left(\mathrm{H}_{2} \mathrm{PO}_{4}\right)_{2}, 2.2 \mathrm{~g} ; \mathrm{KCl}, 0.6 \mathrm{~g}$; boric acid, $\left.0.01 \mathrm{~g}\right)$ in $200 \mathrm{ml}$ of tap water was applied at the rate (urea, $88.6 \mathrm{~kg} / \mathrm{acre}$; $\mathrm{Ca}\left(\mathrm{H}_{2} \mathrm{PO}_{4}\right)_{2}$, $202.1 \mathrm{~kg} / \mathrm{acre}$; KCl, $50.4 \mathrm{~kg} / \mathrm{acre}$; Borax [10.7\% boron], $4.55 \mathrm{~kg} / \mathrm{acre}$ ) recommended for this region of China (Su et al. 2011). Rice straw was removed from an experimental field after grain harvest, dried at $70^{\circ} \mathrm{C}$, and chopped into 2 to $3 \mathrm{~cm}$ segments prior to soil incorporation. Five oilseed rape seeds (Brassica napus L. 'Zhongshuang 11') were sown in each pot and the pots thinned to three seedlings/pot at 5 days and to two seedlings/pot after 10 days. Pots were placed in the greenhouse in a completely random design, and soil moisture maintained at approximately $70 \%$ holding capacity with tap water. The experiment was performed twice over two consecutive years with six replicate pots for each treatment. Experiments were set up in October and run over a period of 29 weeks, ending in May. Three replicate pots for each treatment in each experiment were used to determine total $\% \mathrm{~N}, \mathrm{P}$, and $\mathrm{K}$ in plant shoots and soil available $\mathrm{N}, \mathrm{P}$, and $\mathrm{K}$. The remaining three replicate pots for each treatment were used to determine yield per plant as described below.

To determine total $\%$ plant $\mathrm{N}, \mathrm{P}$, and $\mathrm{K}$, one plant was removed from each replicate pot at 30 days (five-leaf stage) and one plant removed at 150 days (bud stage). The plant was washed to remove soil, dried in an oven at $105^{\circ} \mathrm{C}$ for $30 \mathrm{~min}$, and then dried at $60^{\circ} \mathrm{C}$ for $36 \mathrm{~h}$. Dried plant material was ground to pass through a $100 \mathrm{mesh}$ sieve and total \% plant N, P, and K determined by the Kjeldahl, vanadium molybdate yellow colorimetric, and flame photometry methods, respectively, as described by Lao (1999). Mean total \% $\mathrm{N} /$ plant, mean total \% $\mathrm{P} /$ plant, and mean total \% $\mathrm{K} /$ plant were determined, subjected to ANOVA, and differences among means estimated using LSD in Proc GLM in SAS. Data for the two pot experiments for mean total $\% \mathrm{~N} /$ plant $(P=0.7926$ for five-leaf stage, $P=0.9973$ for bud stage $)$, mean total $\% \mathrm{P} /$ plant $(P=0.5112$ for five-leaf stage, $P=0.9181$ for bud stage), and mean total $\%$ $\mathrm{K} /$ plant $(P=0.9628$ for five-leaf stage, $P=0.3938$ for bud stage $)$ for the five leaf and bud stages were combined $(n=2)$ as there were no significant experiment $\times$ treatment effects.

Soil available N, P, and $\mathrm{K}$ in these greenhouse pot studies was determined as for field studies except $10 \mathrm{~g}$ of soil was removed from each replicate pot. Mean available $\mathrm{mg}$ of $\mathrm{N} / \mathrm{kg}$ of soil, mean $\mathrm{mg}$ of $\mathrm{P} / \mathrm{kg}$ of soil, and mean $\mathrm{mg}$ of $\mathrm{K} / \mathrm{kg}$ of soil were determined, subjected to ANOVA, and differences among means estimated using LSD in Proc GLM in SAS. Data for the two pot experiments for mean available $\mathrm{mg}$ of $\mathrm{N} / \mathrm{kg}$ of soil $(P=0.5634)$, mean $\mathrm{mg}$ of $\mathrm{P} / \mathrm{kg}$ of soil $(P=0.1456)$, and mean $\mathrm{mg}$ of $\mathrm{K} / \mathrm{kg}$ of soil $(P=0.9648)$ were combined $(n=2)$ as there were no significant experiment $\times$ treatment effects.

At harvest the individual plant in each replicate pot was sampled for seed dry weight. Seed were weighed after drying in the sun for two days. Mean yield per pot was determined, subjected to analysis of ANOVA, and differences among means estimated using LSD in Proc GLM in SAS. Data from the two pot experiments were combined prior to analysis $(n=2)$ as there was no experiment $\times$ treatment effect $(P=0.7929)$.

Persistence of isolate Tri-1 in soil. Pots $(20 \mathrm{~cm}$ height $\times$ $21 \mathrm{~cm}$ diameter) were filled with $5 \mathrm{~kg}$ of the same dried, sieved soil used in the above greenhouse pot assays, and the following treatments applied: (i) soil plus no treatment, (ii) soil plus Tri-1, (iii) soil plus oilseed rape (one seed/ pot), (iv) soil plus oilseed rape plus Tri-1, (v) soil plus straw, and (vi) soil plus straw plus Tri-1. Fertilizer and straw were mixed into the soil as per the greenhouse plant growth promotion pot experiment above. Isolate Tri-1 was grown 
4 days in $\mathrm{PDB}$ at $28^{\circ} \mathrm{C}$ and resuspended in $0.9 \% \mathrm{NaCl}$, and $10 \mathrm{ml}$ of the suspension (approximately $5 \times 10^{5}$ Tri- 1 spores $/ \mathrm{ml}$ ) was applied to the appropriate treatments as a drench. Sterile $0.9 \% \mathrm{NaCl}(10 \mathrm{ml})$ was applied to treatments that did not receive the Tri-1 application. Pots were placed in the greenhouse in a completely random design, and soil moisture was maintained at approximately $70 \%$ holding capacity with tap water. The experiment was performed twice with three replicate pots for each treatment. Treatments were sampled at various times over a 180-day period by dilution-plating onto PDA containing hygromycin and Trichoderma-like colonies counted. Mean $\log _{10} \mathrm{CFU} / \mathrm{g}$ of soil were determined, subjected to ANOVA, and differences among means estimated using LSD in Proc GLM in SAS. Data from the two pot experiments were combined $(n=2)$ prior to analysis as there was no significant experiment $\times$ treatment effect $(P=0.8520)$.

Growth of isolate Tri-1 on rice straw in vitro and cellulase assays. To determine growth of Tri- 1 on rice straw, $5 \mathrm{~g}$ of dried rice straw was added to $4.0 \mathrm{ml}$ of tap water in a $250-\mathrm{ml}$ Erlenmeyer flask. The contents of the flask were autoclaved at $120^{\circ} \mathrm{C}$ for $30 \mathrm{~min}$, cooled, and inoculated with a $1.0 \mathrm{-ml}$ suspension of Tri- $1\left(1 \times 10^{3}\right.$ spores $\left./ \mathrm{ml}\right)$. Tri- 1 was grown 5 days on PDA at $28^{\circ} \mathrm{C}$ prior to suspension in sterile $0.9 \% \mathrm{NaCl}$. Control flasks received $1.0 \mathrm{ml}$ of sterile $0.9 \% \mathrm{NaCl}$. Flasks were incubated at $160 \mathrm{rpm}$ at $28^{\circ} \mathrm{C}$ and Tri-1-like populations were determined periodically by dilution-plating onto PDA containing hygromycin. The experiment was performed twice with three replicates per treatment. Data from the two experiments were combined $(n=2)$ prior to analysis.

For cellulase assays, isolate Tri- 1 was grown in PDB for 4 days at $28^{\circ} \mathrm{C}$ and $160 \mathrm{rpm}$, centrifuged at $2,460 \times g$, passed through a $0.45 \mu$ membrane, and the culture filtrate used immediately. Noninoculated PDB, centrifuged and filtered the same as for the Tri-1 cultures, was used as the control. Cellulase activity was determined by the dinitrosalicylic acid method using filter paper as substrate (Ghose 1987; Zhang 2002) and was conducted at $50^{\circ} \mathrm{C}$ in $50 \mathrm{mM}$ citrate buffer, $\mathrm{pH}$ 4.8. One unit of cellulase activity was defined as the amount of enzyme that released $1 \mu \mathrm{g}$ of glucose reducing equivalent $/ \mathrm{min} / \mathrm{ml}$ of culture filtrate. Cellulase assays were conducted twice with three replicates for each treatment. Data from both experiments were combined prior to determination of mean unit cellulase activity with standard deviation.

\section{RESULTS}

Impact of biological and fungicide treatments on control of $S$. sclerotiorum on oilseed rape and on straw decomposition in field trials. Two field trials were conducted in fields that contained sclerotia of $S$. sclerotiorum remaining from two previous trials where sclerotia of this pathogen were added to the soil. The treatment containing residual straw in the field + formulated Tri-1 was significantly greater than the nontreated control and the control + fungicide spray treatment applied at flowering with regard to yield (Table 1). Yield data associated with the residual straw and the residual straw + noninoculated formulation treatments suggested that the straw and the formulation ingredients (oilseed rape seedcake and rice straw) contributed to this increase in yield. However, the straw + formulated Tri-1 treatment was the only strictly biologically based treatment that had significantly greater yield than the control + fungicide spray treatment suggesting that Tri-1 contributed slightly to this yield increase. The control + fungicide spray treatment applied at flowering was not significantly greater than the nontreated control with regard to oilseed rape seed yield but did have some benefit when applied in combination with the biologically based treatments as this resulted in incremental improvements in yield (Table 1).

The impact of these treatments on incidence of disease caused by S. sclerotiorum was also evaluated in these two field trials. Disease incidence in field trials with the residual straw + formulated Tri-1 treatment was significantly lower than with the nontreated control suggesting that impacts of the straw + formulated Tri-1 treatment on yield were at least partially associated with biological control of this pathogen (Table 1). This disease control was better than that provided by the control + fungicide spray treatment. The residual straw and the straw + noninoculated formulation treatments also resulted in a reduction in disease incidence relative to the nontreated control. However, the straw + formulated Tri- 1 treatment was the only strictly biologically based treatment with an associated disease incidence that was significantly lower than the control + fungicide spray treatment. The fungicide spray (control + fungicide spray treatment) alone did provide some disease control with an associated disease incidence significantly lower than that of the nontreated control.

The impact of formulated Tri-1 applied in combination with residual rice straw on germination of sclerotia of $S$. sclerotiorum was evaluated in these field studies with sclerotia applied to soil in mesh bags, allowing both recovery of the sclerotia and the colonization of sclerotia by Tri-1 and the indigenous microflora (Fig. 1). Inhibition of sclerotial germination by the straw + formulated Tri-1 treatment trended greater than the nontreated control at 90 , 120 , and 150 days but was not significantly greater than the nontreated control at any time point. $95 \%$ confidence intervals for all treatments overlapped at each time point.

The presence of Tri-1 did not result in a detectable reduction of straw biomass in the field studies. There were no significant differences $(P \leq 0.05)$ in straw biomass in the field studies between the straw only, straw + noninoculated formulation, and straw + formulated Tri-1 treatments. Mean residual straw associated these treatments was $25.0 \mathrm{~g} / 0.072 \mathrm{~m}^{3}, 22.8 \mathrm{~g} / 0.072 \mathrm{~m}^{3}$, and 22.3 $\mathrm{g} / 0.072 \mathrm{~m}^{3}$, respectively.

Soil nutrient status and soil enzyme activities in field trials. The impact of the residual rice straw + formulated Tri-1 treatment on the status of soil available $\mathrm{N}, \mathrm{P}$, and $\mathrm{K}$ and organic matter was determined at 150 days after planting in field studies

TABLE 1. Impact of formulated Trichoderma sp. Tri-1 (Tri-1) on disease incidence and oilseed rape seed yield in field experiments ${ }^{\mathrm{z}}$

\begin{tabular}{|c|c|c|}
\hline Treatment & Mean disease incidence & Mean yield $(\mathrm{g}) / 120$ plants \\
\hline Control (no straw or formulated Tri-1) & $17.11 \mathrm{~A}$ & $1,863.1 \mathrm{E}$ \\
\hline Control + fungicide spray & $11.31 \mathrm{~B}$ & $1,910.2 \mathrm{DE}$ \\
\hline Straw only & $11.42 \mathrm{~B}$ & $1,952.4 \mathrm{CD}$ \\
\hline Straw + fungicide spray & $8.73 \mathrm{BCD}$ & $1,967.0 \mathrm{BCD}$ \\
\hline Straw + noninoculated formulation & $10.86 \mathrm{BC}$ & $1,983.2 \mathrm{ABCD}$ \\
\hline Straw + noninoculated formulation + fungicide spray & $7.80 \mathrm{D}$ & $2,031.0 \mathrm{AB}$ \\
\hline Straw + formulated Tri-1 & $8.38 \mathrm{CD}$ & $2,023.9 \mathrm{AB}$ \\
\hline Straw + formulated Tri- $1+$ fungicide spray & $6.82 \mathrm{D}$ & $2,047.5 \mathrm{~A}$ \\
\hline LSD & 2.69 & 74.6 \\
\hline
\end{tabular}

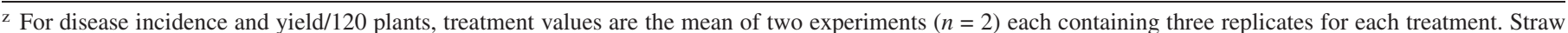
was residual rice straw in soil, noninoculated formulation was the oilseed rape seedcake mixed with rice straw, formulated Tri-1 was this formulation inoculated with Tri-1, and fungicide spray was the chemical pesticide carbendazim applied as a foliar spray at flowering. Repeat experiments were conducted in consecutive years at the same field location. Means were separated by least significant difference (LSD). Values within a column followed by the same letter are not significantly different $(P \leq 0.05)$. 
(Table 2). Mean available $\mathrm{P}$ and $\mathrm{K}$ were significantly greater than the nontreated control with the straw + formulated Tri-1 treatment. However, increases in available nutrients were due to the rapeseed seedcake and rice straw portion of the formulation itself, not Tri-1. Inoculation of Tri-1 into this formulation did not improve $\mathrm{P}$ or $\mathrm{K}$ availability as the straw + formulated Tri-1 and straw + noninoculated formulation treatments were similar for these two nutrients. All treatments were similar with regard to soil available $\mathrm{N}$ and organic matter in these field studies.

Soil acid phosphatase, invertase, and urease activities were all significantly greater in the residual straw + formulated Tri-1 treatment than the nontreated control in field studies (Table 3). Inoculation of Tri-1 into this formulation did not influence these enzyme activities as the straw + noninoculated formulation (no Tri-1) and the straw + formulated Tri- 1 treatments were similar for all soil enzyme activities. Residual straw alone also contributed to some enzyme activities in field studies.

Greenhouse plant growth promotion pot studies. The impact of the residual straw + formulated Tri-1 treatment on promotion of growth of oilseed rape was evaluated in two pot studies containing sieved soil that was devoid of sclerotia of S. sclerotiorum (Table 4). There was no evidence of disease with any treatments in either of these pot studies (data not shown). The residual straw + formulated Tri- 1 treatment resulted in increased yield relative to the nontreated control while the straw alone and the straw + noninoculated formulation treatments did not, suggesting that Tri-1 promoted growth of oilseed rape. However, components of this treatment other than Tri-1 influenced the nutritional status of oilseed rape plants and soil (Fig. 2 and Table 4). The straw + noninoculated formulation treatment increased mean total \% $\mathrm{N} /$ plant at the five-leaf stage (30 days after planting) and bud stage (150 days after planting) and mean total \% P/plant at the bud stage relative to the nontreated control in these pot studies (Fig. 2). Isolate Tri-1 did not increase $\mathrm{N}$ or $\mathrm{P}$ content of oilseed rape plants as the straw + formulated Tri- 1 and the straw + noninoculated formulation treatment were similar with regard to plant $\mathrm{N}$ and $\mathrm{P}$ content. No treatment increased mean total $\% \mathrm{~K} /$ plant relative to the nontreated control in pot studies. The impact of formulated Tri-1 on the status of soil available N, P, and $\mathrm{K}$ and organic matter was also determined at 150 days after planting oilseed rape (bud stage) in these pot studies (Table 4). Mean available N, P, and K was significantly greater with the straw + noninoculated formulation than the nontreated control. N, P, or K availability in soil was not increased in the straw + formulated Tri-1 treatment relative to the straw + noninoculated formulation treatment.

Persistence of Tri-1 in bare soil, on oilseed rape, and on rice straw. The persistence of Tri-1 in bare soil, on oilseed rape, and in the presence of rice straw was determined in greenhouse pot studies (Fig. 3). Populations of hygromycin-resistant, Tri-1-like fungi were greatest in the rice straw + Tri- 1 treatment for the duration of the 180 day experiment suggesting that rice straw supported growth of Tri-1 in situ. Populations of these Tri-1-like fungi were high in the control straw treatment but significantly lower than found with the straw + Tri-1 treatment. Oilseed rape appeared to support populations of Tri-1-like fungi, although not to the same extent as the rice straw. Finally, populations of hygromycin-resistant, Tri-1-like fungi declined very rapidly in the soil only + Tri-1 treatment, being below $10^{2} \mathrm{CFU} / \mathrm{g}$ of soil after 30 days.

Growth of Tri-1 on rice straw in vitro. Isolate Tri-1 was capable of growth on rice straw in vitro and this isolate produced cellulase in culture; cellulase being potentially capable of degrading the cellulose component of rice straw. Populations of Tri-1-like fungi were $3.0 \pm 0.3 \times 10^{3}, 5.5 \pm 0.2 \times 10^{7}$, and $3.4 \pm 0.2 \times 10^{8}$ $\mathrm{CFU} / \mathrm{ml}$ in vitro on rice straw at $0,7,14$, and 21 days, respectively, with the treatment inoculated with Tri-1. Populations of Tri-1-like fungi were not detectable at any time point with the noninoculated control. Filter paper cellulase activity was detected in culture filtrate
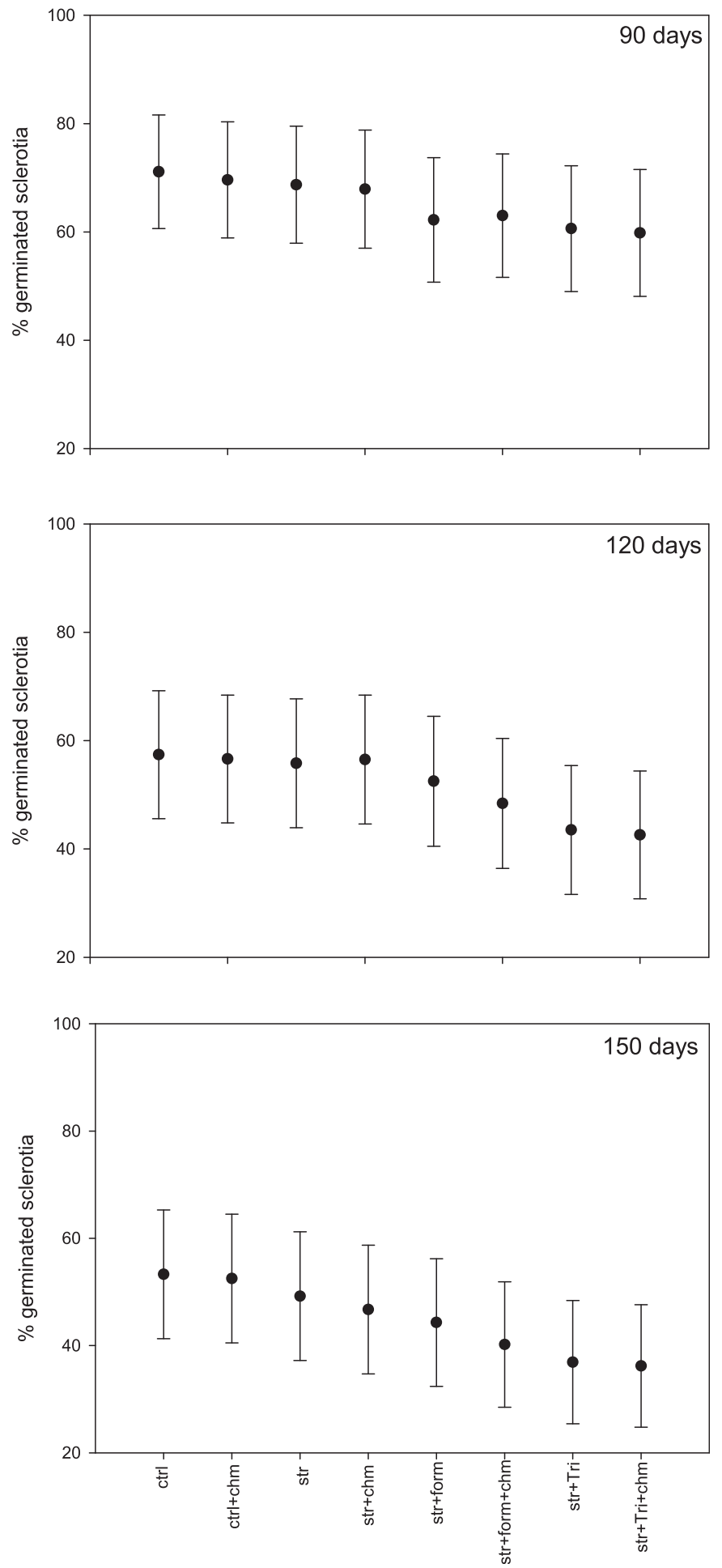

Fig. 1. Inhibition of germination of sclerotia of Sclerotinia sclerotiorum with formulated Trichoderma sp. Tri-1 (Tri-1) applied to soil prior to sowing oilseed rape seed in field experiments. For percent germinated sclerotia, treatment values are the mean of two experiments $(n=2)$ each with three replicates for each treatment. Repeat experiments were conducted in consecutive years at the same field location. Error bars represent the $95 \%$ confidence interval for each mean. Standard error was between 5.3 and 5.9 for means at 90 days, 6.0 and 6.2 for means at 120 days, and 5.8 and 6.2 for means at 150 days. $\mathrm{Ctrl}=$ the nontreated control (no straw or formulated Tri-1), ctrl $+\mathrm{chm}=$ control plus the chemical spray, $\mathrm{str}=$ residual rice straw in soil only, $\mathrm{str}+\mathrm{chem}=$ residual rice straw plus the chemical spray, $\mathrm{str}+$ form $=$ residual rice straw in soil plus the noninoculated formulation, str + form $+\mathrm{chm}=$ straw plus noninoculated formulation plus the chemical spray, $\mathrm{str}+$ Tri $=$ residual rice straw and this formulation inoculated with Tri-1, and $\mathrm{str}+$ Tri $+\mathrm{chm}=$ residual rice straw plus the inoculated formulation plus the chemical spray. 
from Tri-1 grown on PDB (274.9 \pm 21.4 unit) while filter paper cellulase activity was below detectable limits in the noninoculated control.

\section{DISCUSSION}

Our long-term goal is to develop a sustainable disease control strategy for $S$. sclerotiorum on oilseed rape. Oilseed rape is traditionally grown in a rice-oilseed rape rotation in the Yangtzee River basin and along the southeast coast of China (Xiao et al. 2011). Residual rice straw remaining after the rice harvest is either burned or incorporated into the soil in this production system (Jiang et al. 2011; Liu et al. 2007) while oilseed rape seedcake, remaining after oil extraction, is sometimes incorporated into the soil as fertilizer (Hu et al. 2009; Li et al. 2005). A major challenge in the development of sustainable disease control methods is obtaining consistently effective disease control and yield while working within the confines of the production system. Here we showed that a treatment containing components of this rice-oilseed rape production system, augmented with Trichoderma sp. Tri-1 (Tri-1), has promise for control of $S$. sclerotiorum on oilseed rape. This multicomponent treatment used the residual rice straw remaining after the rice harvest as well as the oilseed rape seedcake fertilizer as a formulation for Tri-1. This treatment increased oilseed rape seed yield and decreased disease incidence relative to the nontreated and fungicide controls in fields containing sclerotia of this pathogen (Table 1). The nontreated control was bare soil without the rice straw residue while the fungicide control was the recommended fungicide sprayed onto oilseed rape plants at flowering. Yield and disease incidence data associated with the various components of this multicomponent treatment suggested that all components contributed, with incremental improvements in both yield and disease incidence as more components were added.

Increases in oilseed rape seed yield associated with application of the treatment containing the noninoculated oilseed rape seedcake formulation (no Tri-1) and rice straw (Table 1) were probably due, at least in part, to the impact of this treatment on soil fertility. The oilseed rape seedcake portion of this treatment contained $5.81 \% \mathrm{~N}, 0.02 \% \mathrm{P}$, and $1.03 \% \mathrm{~K}$ (X. Hu, unpublished data) and as noted, has been used as a fertilizer in oilseed rape production in China. Soil available N, P, and K were increased with this treatment in pot studies and soil available $\mathrm{P}$ and $\mathrm{K}$ were increased in the field trials (Tables 2 and 4). Improvements in soil fertility were evidenced by higher $\mathrm{N}$ and $\mathrm{P}$ content in oilseed rape plants in pot experiments (Fig. 2). Application of the treatment containing the noninoculated formulation to fields containing residual rice straw also reduced incidence of disease (Table 1). Increased acid phosphatase, invertase, and urease activity in soil associated with this treatment (Table 3) indicated increased

TABLE 2. Soil available N, P, and K and soil organic matter (OM) at 150 days with applications of Trichoderma sp. Tri-1 (Tri-1) in the field ${ }^{\mathrm{z}}$

\begin{tabular}{|c|c|c|c|c|}
\hline Treatment & $\begin{array}{l}\text { Mean available mg of } \\
\mathrm{N} / \mathrm{kg} \text { of soil }\end{array}$ & $\begin{array}{c}\text { Mean available } \mathrm{mg} \text { of } \\
\mathrm{P} / \mathrm{kg} \text { of soil }\end{array}$ & $\begin{array}{c}\text { Mean available mg of } \\
\mathrm{K} / \mathrm{kg} \text { of soil }\end{array}$ & $\begin{array}{c}\text { Mean } \mathrm{g} \text { of } \mathrm{OM} / \mathrm{kg} \\
\text { of soil }\end{array}$ \\
\hline Control (no straw or formulated Tri-1) & $95.65 \mathrm{~A}$ & $13.09 \mathrm{~B}$ & $127.33 \mathrm{C}$ & $15.02 \mathrm{~A}$ \\
\hline Straw only & $97.58 \mathrm{~A}$ & $14.10 \mathrm{~B}$ & $131.16 \mathrm{~B}$ & $15.26 \mathrm{~A}$ \\
\hline Straw + noninoculated formulation & $98.41 \mathrm{~A}$ & $15.56 \mathrm{~A}$ & $135.83 \mathrm{~A}$ & $15.31 \mathrm{~A}$ \\
\hline Straw + formulated Tri-1 & $97.92 \mathrm{~A}$ & $15.69 \mathrm{~A}$ & $134.82 \mathrm{~A}$ & $15.28 \mathrm{~A}$ \\
\hline LSD & 2.9008 & 1.1938 & 2.7919 & 1.0414 \\
\hline
\end{tabular}

${ }^{\mathrm{z}}$ For mean available $\mathrm{mg}$ of $\mathrm{N} / \mathrm{kg}$ of soil, mean $\mathrm{mg}$ of P/kg of soil, mean $\mathrm{mg}$ of $\mathrm{K} / \mathrm{kg}$ of soil, and mean $\mathrm{g}$ of organic matter $/ \mathrm{kg}$ of soil, treatment values are the mean of two experiments $(n=2)$ each containing three replicates for each treatment. Straw was residual rice straw in soil, noninoculated formulation was the oilseed rape seedcake mixed with rice straw, and formulated Tri-1 was this formulation inoculated with Tri-1. Means were separated by least significant difference (LSD). Values within a column followed by the same letter are not significantly different $(P \leq 0.05)$.

TABLE 3. Soil acid phosphatase, invertase, and urease at 150 days with applications of Trichoderma sp. Tri-1 (Tri-1) in the field ${ }^{\mathrm{z}}$

\begin{tabular}{lccc}
\hline Treatment & Mean unit of acid phosphatase & Mean unit of invertase & Mean unit of urease \\
\hline Control (no straw or formulated Tri-1) & $22.03 \mathrm{C}$ & $9.94 \mathrm{C}$ & $0.40 \mathrm{~B}$ \\
Straw only & $31.20 \mathrm{~B}$ & $12.94 \mathrm{~B}$ & $0.51 \mathrm{~A}$ \\
Straw + noninoculated formulation & $39.44 \mathrm{~A}$ & $15.17 \mathrm{~A}$ & $0.57 \mathrm{~A}$ \\
Straw + formulated Tri-1 & $40.26 \mathrm{~A}$ & $14.99 \mathrm{~A}$ & $0.57 \mathrm{~A}$ \\
LSD & 2.8617 & 1.936 & 0.0612 \\
\hline
\end{tabular}

z One unit of acid phosphatase activity was defined as the amount of enzyme that released $1 \mu \mathrm{g}$ of $p$-nitrophenol equivalents/h/g of soil, one unit of soil invertase activity was defined as the amount of enzyme that released $1 \mathrm{mg}$ of glucose equivalents/g of soil/day, and one unit of urease activity was defined as the amount of enzyme that produced $1 \mathrm{mg}$ of ammonia/g of soil/day. For mean unit of soil acid phosphatase, invertase, and urease activity, treatment values are the mean of two experiments $(n=2)$ each containing three replicates for each treatment. Straw was residual rice straw in soil, noninoculated formulation was the oilseed rape seedcake mixed with rice straw, and formulated Tri-1 was this formulation inoculated with Tri-1. Means were separated by least significant difference (LSD). Values within a column followed by the same letter are not significantly different $(P \leq 0.05)$.

TABLE 4. Soil available N, P, and K and oilseed rape seed yield with applications of Trichoderma sp. Tri-1 (Tri-1) in greenhouse pot studies ${ }^{\mathrm{Z}}$

\begin{tabular}{|c|c|c|c|c|}
\hline Treatment & $\begin{array}{c}\text { Mean available mg of } \\
\text { N/kg of soil }\end{array}$ & $\begin{array}{c}\text { Mean available mg of } \\
\mathrm{P} / \mathrm{kg} \text { of soil }\end{array}$ & $\begin{array}{c}\text { Mean available } \mathrm{mg} \text { of } \\
\mathrm{K} / \mathrm{kg} \text { of soil }\end{array}$ & Mean yield/plant (g) \\
\hline Control (no straw or formulated Tri-1) & $96.32 \mathrm{~B}$ & $14.22 \mathrm{~B}$ & $126.14 \mathrm{C}$ & $13.3 \mathrm{~B}$ \\
\hline Straw only & $98.20 \mathrm{AB}$ & $14.55 \mathrm{~B}$ & $131.61 \mathrm{~B}$ & $14.2 \mathrm{~B}$ \\
\hline Straw + noninoculated formulation & $99.95 \mathrm{~A}$ & $15.87 \mathrm{~A}$ & $136.61 \mathrm{~A}$ & $14.0 \mathrm{~B}$ \\
\hline Straw + formulated Tri-1 & $99.48 \mathrm{~A}$ & $15.80 \mathrm{~A}$ & $136.83 \mathrm{~A}$ & $15.2 \mathrm{~A}$ \\
\hline LSD & 2.432 & 0.7854 & 4.7471 & 0.95 \\
\hline
\end{tabular}

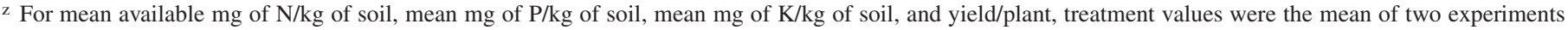
$(n=2)$ each containing three replicates for each treatment. Straw was residual rice straw in soil, noninoculated formulation was the oilseed rape seedcake mixed with rice straw, and formulated Tri-1 was this formulation inoculated with Tri-1. Means were separated by least significant difference (LSD). Values within a column followed by the same letter are not significantly different $(P \leq 0.05)$. 
microbial activity. It is possible that the impact of this treatment on disease was due to this increased microbial activity. Increased microbial activity in soil has been associated with general suppression of soilborne plant pathogens; general suppression often being enhanced by the addition of organic matter (Weller et al. 2002). Additionally, soil amendment with agricultural residues, such as the rice straw in our experiments, has been shown to reduce carpogenic germination of sclerotia of S. sclerotiorum (Huang et al. 2002).

Inoculation of the oilseed rape seedcake formulation with Tri-1, and application of this inoculated formulation to the soil along with the rice straw that remained in the field, resulted in incremental improvements in yield and disease control (Table 1) suggesting that Tri-1 enhanced performance of this multicomponent treatment. The positive influence on crop yield in the presence of plant pathogens by certain isolates of Trichoderma is extensively documented in the literature (Harman et al. 2004; 2008; Howell 2003). Infestation of agricultural residue soil amendments with Trichoderma or other biological control agents has been shown to enhance suppression of carpogenic germination of sclerotia of S. sclerotiorum (Huang et al. 2002) and plant-beneficial effects of these Trichoderma isolates have long been attributed to their direct effects on pathogens through mycoparasitism or antibiosis (Harman et al. 2004; 2008; Howell 2003). There was also evidence that increases in oilseed rape seed yield were due to plant growth promotion by Tri-1 (Table 4). Certain Trichoderma spp. may help plants tolerate disease through plant growth promotion by stimulating plant root and shoot growth and changing the nutritional status of the plants (Harman et al. 2004; Howell 2003).

Another objective of this study was to determine if application of the oilseed rape seedcake formulation inoculated with Tri-1 enhanced degradation of the rice straw remaining in the field after harvesting rice. This would be beneficial as the practice of burning rice straw after the rice harvest results in environmental pollution and loss of soil carbon while incorporation of the rice straw into the soil helps retain soil carbon but decomposition is slow (Mandal et al. 2004). Trichoderma are effective colonizers of cellulosic material and are associated with decaying plant material (Broder and Wagner 1988; Schuster and Schmoll 2010). In experiments reported here or elsewhere (Hu et al. 2010), Tri-1 was shown to grow on, and decompose, rice straw. However,

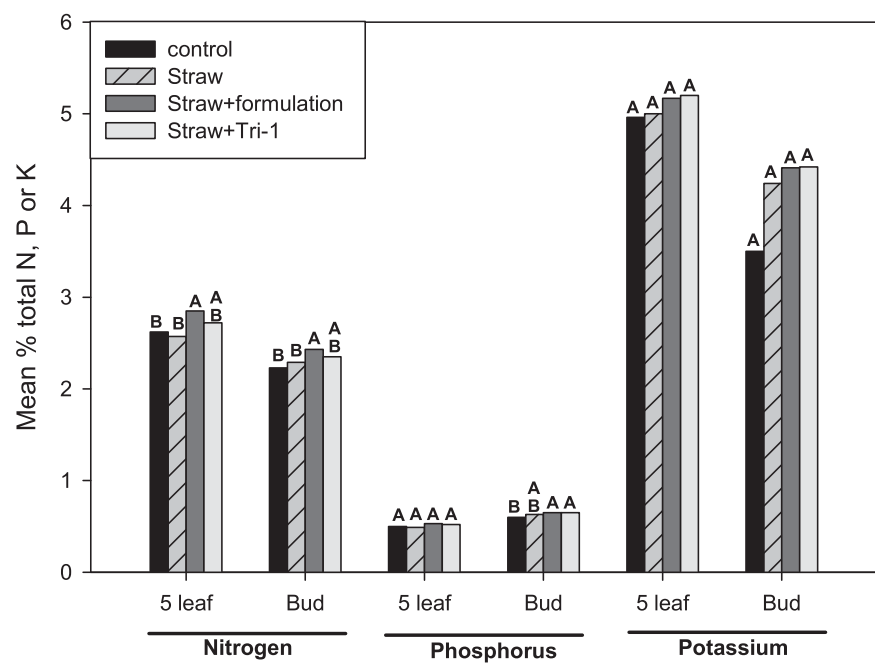

Fig. 2. Oilseed rape N, P, and K content associated with biologically based treatments applied to soil prior to sowing oilseed rape seed in greenhouse pot studies. 5 leaf, five-leaf stage, 30 days after planting; and bud, bud stage, 150 days after planting. Treatment values are the mean of two experiments $(n=2)$ each with three replicates for each treatment. Means were separated by least significant difference. Bars within a cluster with the same letter are not significantly different $(P<0.05)$. application of the oilseed rape seedcake formulation inoculated with Tri-1 did not substantially decompose the rice straw in our field experiments (Table 1).

A potential benefit of the residual rice straw to our sustainable disease control strategy may be in providing Tri-1 a nutrient source in the field. Trichoderma spp. have been shown to be ubiquitous. However, these fungi persist poorly in soil in the absence of a nutrient source (Adams 1990; Papavizas 1985). It is thought that for effective mycoparasitism to occur in soil, hyphae of Trichoderma fungal antagonists must grow from a nutrient source, contact the pathogen propagule, such as a sclerotium, and parasitize this propagule (Knudsen and Bin 1990; Knudsen et al. 1991b). It is also thought that the extent of mycoparasitism of sclerotia of sclerotial pathogens such as $S$. sclerotiorum depends on the density and relative spatial distribution of these sclerotia and the fungal antagonist (Knudsen and Bin 1990; Knudsen et al. 1991a). The thorough distribution of rice straw in the field resulting from rice being the preceding rice crop may help adequately position Tri-1 in the field, with a food base supporting a dense population of this fungal antagonist, to effectively parasitize sclerotia of $S$. sclerotiorum and control this disease on oilseed rape. We showed that populations of Tri-1 were more dense in soil in the presence of rice straw (Fig. 3) and prior studies have shown that Trichoderma were more effective in controlling disease when added to soil with nutrient sources, including plant tissue (Adams 1990; Orr and Knudsen 2004). Future field studies will test this hypothesis by comparing disease control by this Tri-1 formulation applied to bare soil with that achieved by application of this formulation to soil containing rice straw.

Our strategy to enhance consistency of disease control performance has been to develop formulations, some of which contain combinations of microbes, for use in multiple application methods targeting different aspects of the disease cycle. We now have another application method and biologically based treatment, a formulation of the mycoparasitic isolate Tri-1 (Hu et al. 2013c) applied to the soil prior to planting the oilseed rape crop, but after harvest of the rice crop, to use in combination with our Bacillus isolates applied as seed treatments or foliar sprays (Hu et al. 2011; 2013a; 2014). Although we have not demonstrated it yet, these different strains (Bacillus

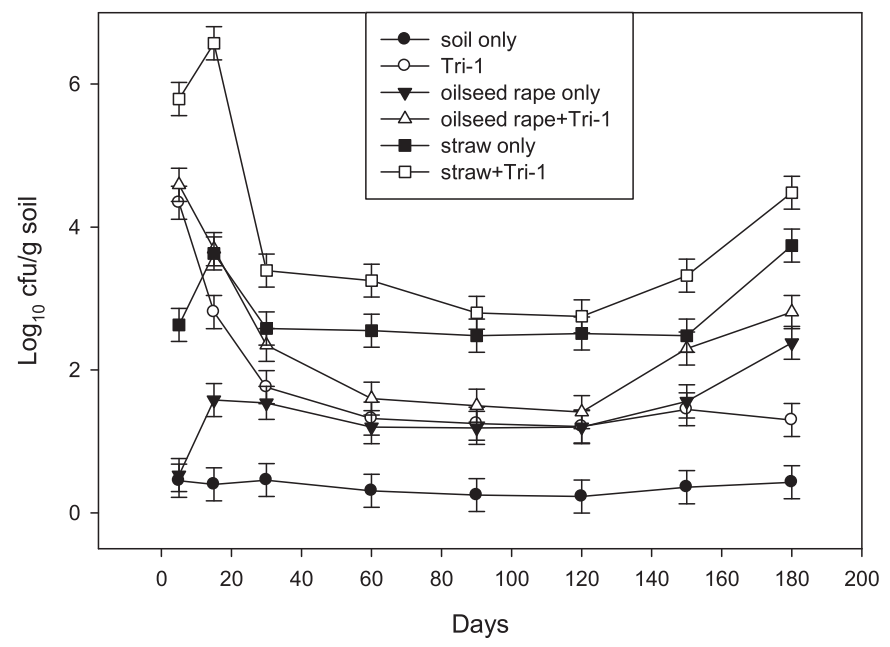

Fig. 3. Persistence of Trichoderma sp. Tri-1 (Tri-1) in association with bare soil, oilseed rape, and straw in greenhouse pot studies. For mean $\log _{10} \mathrm{CFU} / \mathrm{g}$ of soil, treatment values are the mean of two experiments $(n=2)$ each containing three replicates for each treatment. Means were separated by least significant difference (LSD). Error bars represent the LSD from each datapoint. LSD was 0.2309. Approximately $5 \times 10^{5} \mathrm{CFU}$ Tri- 1 were applied to treatments containing this fungus. Soil only, treatment consisted of soil only, no Tri- 1 was added; Tri-1, Tri- 1 was added to the soil; oilseed rape only, treatment consisted of oilseed rape grown in soil; oilseed rape + Tri-1, Tri-1 was added to oilseed rape in soil; straw only, treatment consisted of straw added to soil; and straw + Tri-1, Tri-1 was added to straw in soil. 
isolates A6, BY-2, Tu-100; Tri-1) and application methods (seed treatment, application prior to planting) should be compatible as they target different aspects of the cropping and disease cycles. In future work we will determine if combinations of these strains and application methods result in more consistent disease control over a variety of environmental conditions (soil-type, temperature, soil moisture, etc.) than the use of individual strains or application methods. It should be noted that the use of our formulation containing the Tri-1 isolate was compatible with the fungicide spray treatment. An incremental reduction in disease incidence and an incremental increase in oilseed rape seed yield in our field trials were associated with some of the biologically based treatments when combined with the fungicide spray treatment applied at flowering (Table 1). The compatibility of these control measures may allow a second approach for more sustainable oilseed rape production; the use of the Tri-1 formulation applied prior to sowing oilseed rape seed in combination with reduced rates of fungicide applied at oilseed rape flowering.

\section{ACKNOWLEDGMENTS}

We thank B. Vinyard, Director, Statistics Group, USDA-ARS, Henry A. Wallace Beltsville Agricultural Research Center, Beltsville, MD 20705 for help with statistics. This work was funded by Special Funds from the National Scientific Support Program of China (contract number 2010BAD01B09), Introducing International Advanced Agricultural Science and Technology Program (contract number 2014-Z4), and Fundamental Research Incremental Program from Chinese Academy of Agricultural Sciences (contract number 2014ZL029).

\section{LITERATURE CITED}

Abawi, G. S., and Grogan, R. G. 1979. Epidemiology of diseases caused by Sclerotinia species. Phytopathology 69:899-904.

Adams, P. B. 1990. The potential of mycoparasites for biological control of plant diseases. Annu. Rev. Phytopathol. 28:59-72.

Bao, S. D. 2000. Pages 30-36 in: Soil Agrochemical Analysis, 3rd ed. China Agriculture Press, Beijing.

Bardin, S. D., and Huang, H. C. 2001. Research on biology and control of Sclerotinia diseases in Canada. Can. J. Plant Pathol. 23:88-98.

Boland, G. J. 2004. Fungal viruses, hypovirulence, and biological control of Sclerotinia species. Can. J. Plant Pathol. 26:6-18.

Boland, G. J., and Hall, R. 1994. Index of plant hosts of Sclerotinia sclerotiorum. Can. J. Plant Pathol. 16:93-108.

Broder, M. W., and Wagner, G. H. 1988. Microbial colonization and decomposition of corn, wheat, and soybean residue. Soil Sci. Soc. Am. J. 52:112-117.

Fernando, W. G. D., Nakkeeran, S., and Zhang, Y. 2004. Ecofriendly methods in combating Sclerotinia sclerotiorum (Lib.) de Bary. Recent Res. Dev. Environ. Biol. 1:329-347.

Fernando, W. G. D., Nakkeeran, S., Zhang, Y., and Savchuk, S. 2007. Biological control of Sclerotinia sclerotiorum (Lib.) de Bary by Pseudomonas and Bacillus species on canola petals. Crop Prot. 26:100-107.

Fravel, D. R. 1998. Use of Sporidesmium sclerotivorum for biocontrol of sclerotial plant pathogens. Pages 37-47 in: Plant-Microbe Interactions and Biological Control. G. J. Boland and L. D. Kuykendall, eds. Marcel Dekker, New York.

Fravel, D. R. 2005. Commercialization and implementation of biocontrol. Annu. Rev. Phytopathol. 43:337-359.

Fuller, P. A., Coyne, D. P., and Steadman, J. R. 1984. Inheritance of resistance to white mold disease in a diallel cross of dry beans. Crop Sci. 24:929-933.

Ghose, T. K. 1987. Measurement of cellulose activities. Pure Appl. Chem. 58: 257-268.

Glare, T., Caradus, J., Gelernter, W., Jackson, T., Keyhani, N., Köhl, J., Marrone, P., Morin, L., and Stewart, A. 2012. Have biopesticides come of age? Trends Biotechnol. 30:250-258.

Guan, C. Y. 2011. The development direction of the oilseed rape industry in China. Grain Sci. Technol. Econ. 36:5-6.

Harman, G. E., Björkman, T., Ondik, K., and Shoresh, M. 2008. Changing paradigms on the mode of action and uses of Trichoderma spp. for biocontrol. Outl. Pest Manage. 19:24-29.

Harman, G. E., Howell, C. R., Viterbo, A., Chet, I., and Lorito, M. 2004. Trichoderma species - opportunistic, avirulent plant symbionts. Nat. Rev. Microbiol. 2:43-56.

Howell, C. R. 2003. Mechanisms employed by Trichoderma species in the biological control of plant diseases: The history and evolution of current concepts. Plant Dis. 87:4-10.
Hu, X., Roberts, D. P., Jiang, M., and Zhang, Y. 2005. Decreased incidence of disease caused by Sclerotinia sclerotiorum and improved plant vigor of oilseed rape with Bacillus subtilis Tu-100. Appl. Microbiol. Biotechnol. 68: 802-807.

Hu, X., Roberts, D. P., Maul, J. E., Emche, S. E., Liao, X., Guo, X., Liu, X., McKenna, L. F., Buyer, J. S., and Liu, S. 2011. Formulations of the endophytic bacterium Bacillus subtilis Tu-100 suppress Sclerotinia sclerotiorum on oilseed rape and improve plant vigor in field trials conducted at separate locations. Can. J. Microbiol. 57:539-546.

Hu, X., Roberts, D. P., Xie, L., Maul, J. E., Yu, C., Li, Y., Jing, M., Liao, X., Che, X., and Liao, X. 2014. Formulations of Bacillus subtilis BY-2 suppress Sclerotinia sclerotiorum on oilseed rape in the field. Biol. Control 70:54-64.

Hu, X., Roberts, D. P., Xie, L., Maul, J. E., Yu, C., Li, Y., Zhang, S., and Liao, X. 2013a. Bacillus megaterium A6 suppresses Sclerotinia sclerotiorum on oilseed rape in the field and promotes oilseed rape growth. Crop Prot. 52: $151-158$

Hu, X., Roberts, D. P., Xie, L., Maul, J. E., Yu, C., Li, Y., Zhang, S., and Liao, X. 2013b. Development of a biologically based fertilizer, incorporating Bacillus megaterium A6, for improved phosphorus nutrition of oilseed rape. Can. J. Microbiol. 59:231-236.

Hu, X., Webster, G., Xie, L., Yu, C., and Liao, X. 2013c. A new mycoparasite, Aspergillus sp. ASP-4, parasitizes the sclerotia of Sclerotinia sclerotiorum. Crop Prot. 54:15-22.

Hu, X., Yu, C. B., Li, Y., Liu, S., Liao, X., Zheng, C. L., and Wu, X. M. 2009. Study of bio-fertilizer on growth promotion of oilseed rape and prevention of Sclerotinia. Chin. J. Oil Crop Sci. 31:540-543.

Hu, X., Zhang, M. H., Yu, C. B., Xie, L., Chen, Y., Li, Y., Liu, S., Feng, X., Zhang, C., and Liao, X. 2010. Isolated fungal strains inhibiting sclerotial germination and their biocontrol properties. Chin. J. Oil Crop Sci. 32: 567-570

Huang, H.-C., Erickson, R. S., Chang, C., Moyer, J. R., Larney, F. J., and Huang, J.-W. 2002. Organic soil amendments for control of apothecial production of Sclerotinia sclerotiorum. Plant Path. Bull. 11:207-214.

Ji, P., Campbell, H. L., Kloepper, J. W., Jones, J. B., Suslow, T. V., and Wilson, M. 2006. Integrated biological control of bacterial speck and spot of tomato under field conditions using foliar biological control agents and plant growth-promoting rhizobacteria. Biol. Control 36:358-367.

Jiang, Y. H., Yu, Z. R., and Ma, Y. 2011. The effect of stubble return on agroecology and crop growth. Chin. J. Soil Sci. 32:209-213.

Kandeler, E., and Gerber, H. 1988. Short-term assay of soil urease activity using colorimetric determination of ammonia. Biol. Fertil. Soils 6: 68-72.

Knudsen, G. R., and Bin, L. 1990. Effects of temperature, soil moisture, and wheat bran on growth of Trichoderma harzianum from alginate pellets. Phytopathology 80:724-727.

Knudsen, G. R., Eschen, D. J., Dandurand, L. M., and Bin, L. 1991a. Potential for biocontrol of Sclerotinia sclerotiorum through colonization of sclerotia by Trichoderma harzianum. Plant Dis. 75:466-470.

Knudsen, G. R., Eschen, D. J., Dandurand, L. M., and Wang, Z. G. 1991 b. Method to enhance growth and sporulation of pelletized biocontrol fungi. Appl. Environ. Microbiol. 57:2864-2867.

Lao, J. 1999. Determination of plant ash and various nutrient elements. Pages 263-271 in: Analysis of Soil Agrochemicals. S. Bao, ed. China Agricultural Press, Beijing.

Lemanceau, P., and Alabouvette, C. 1991. Biological control of Fusarium diseases by fluorescent Pseudomonas and non-pathogenic Fusarium. Crop Prot. 10:279-286.

Li, C., Li, H., Siddique, A. B., Sivasithamparam, K., Salisbury, P., Banga, S. S., Banga, S., Chattopadhyay, C., Kumar, A., Singh, R., Singh, D., Agnihotri, A., Liu, S., Li, Y. C., Tu, J., Fu, T., Wang, Y., and Barbetti, M. J. 2007. The importance of the type and time of inoculation and assessment in the determination of resistance in Brassia napus and B. juncea to Sclerotinia sclerotiorum. Aust. J. Agric. Res. 58:1198-1203.

Li, Z. X., Xing, D. Y., Wang, X. L., Huang, P., Jiang, M., and Hu, X. 2005. Primary study on growth-promoting and biocontrol effects of PGPG microbial agents on rapeseed. Chin. J. Oil Crop Sci. 27:51-54.

Liu, S. P., Nie, X. T., Dai, Q., Huo, Z. Y., and Xu, K. 2007. Effects of interplanting with zero tillage and straw manuring on rice growth and grain quality. Chin. J. Rice Sci. 21:71-76.

Lu, G. 2003. Engineering Sclerotinia sclerotiorum resistance in oilseed crops. Afr. J. Biotechnol. 2:509-516

Ma, H.-X., Feng, X.-J., Chen, Y., Chen, C.-J., and Zhou, M.-G. 2009b. Occurrence and characterization of dimethachlon insensitivity in Sclerotinia sclerotiorum in Jinagsu Province of China. Plant Dis. 93:36-42.

Ma, X.-H., Chen, Y., Wang, J.-X., Yu, W.-Y., Tang, Z.-H., Chen, C.-J., and Zhou, M.-G. 2009a. Activity of carbendazim, dimethachlon, iprodione, procymidone and boscalid against Sclerotinia stem rot in Jinagsu Province of China. Phytoparasitica 37:421-429. 
Mandal, K. G., Misra, A. K., Hati, K. M., Bandyopadhyay, K. K., Ghosh, P. K., and Mohanty, M. 2004. Rice residue-management options and effects on soil properties and crop productivity. Food Agric. Environ. 2:224-231.

Martens, J., Seaman, W., and Atkinson, G. (eds.) 1994. Diseases of Field Crops in Canada. The Canadian Phytopathological Society, ON, Canada.

Min, X. 2008. Formulation methods for three kinds of microbial fertilizer. Fertil. Pesticides 4:89.

Morrall, R. A. A., and Dueck, J. 1982. Epidemiology of Sclerotinia stem rot of rapeseed in Saskatchewan. Can. J. Plant Pathol. 4:161-168.

Nelson, B. 1998. Biology of Sclerotinia. Pages 1-5 in: Proc. $10^{\text {th }}$ International Sclerotinia Workshop. North Dakota State University, Department of Plant Pathology, Fargo.

Olsen, S. R., Cole, C. V., Watanabe, F. S., and Dean, L. A. 1954. Estimation of available phosphorus in soils by extraction with sodium bicarbonate. Government Printing Office, Washington, D.C. USDA Circular 939:1-19.

Orr, K. A., and Knudsen, G. R. 2004. Use of green fluorescent protein and image analysis to quantify proliferation of Trichoderma harzianum in nonsterile soil. Phytopathology 94:1383-1389.

Papavizas, G. C. 1985. Trichoderma and Gliocladium: Biology, ecology, and potential for biocontrol. Annu. Rev. Phytopathol. 23:23-54.

Pierson, E. A., and Weller, D. M. 1994. Use of mixtures of fluorescent pseudomonads to suppress take-all and improve the growth of wheat. Phytopathology 84:940-947.

Purdy, L. H. 1979. Sclerotinia sclerotiorum: History, diseases, symptom pathology, host range, geographic distribution, and impact. Phytopathology 69:875-880.

Raupach, G. S., and Kloepper, J. W. 1998. Mixtures of plant growth-promoting rhizobacteria enhance biological control of multiple cucumber pathogens. Phytopathology 88:1158-1164.

Schinner, F., and von Mersi, W. 1990. Xylanase, CM-cellulase and invertase activity in soil: An improved method. Soil Biol. Biochem. 22:511-515.

Schuster, A., and Schmoll, M. 2010. Biology and biotechnology of Trichoderma. Appl. Microbiol. Biotechnol. 87:787-799.

Stroup, W. W. 2013. Generalized Linear Mixed Models Modern Concepts, Methods and Applications. CRC Press, Boca Raton, FL.

Su, W., Lu, J., Zhou, G., Li, X., Li, Y., and Liu, X. 2011. Influence of strawreturning on rapeseed (Brassica napus L.) growth, soil temperature and moisture. Plant Nutr. Fertil. Sci. 17:366-373.
Tabatabai, M. A., and Bremner, J. M. 1969. Use of $p$-nitrophenyl phosphate for assay of soil phosphatase activity. Soil Biol. Biochem. 1:301-307.

Turkington, T. K., and Morrall, R. A. A. 1993. Use of petal infestation to forecast Sclerotinia stem rot of canola: The influence of inoculum variation over the flowering period and canopy density. Phytopathology 83: 682-689.

Wang, Y., Duan, Y., Wang, J., and Zhou, M. 2015. A new point mutation in the iron-sulfur subunit of succinate dehydrogenase confers resistance to boscalid in Sclerotinia sclerotiorum. Mol. Plant Pathol. 16:653-661.

Weller, D. M., Raaijmaker, J. M., McSpadden Gardener, B. B., and Thomashow, L. S. 2002. Microbial populations responsible for specific soil suppressiveness to plant pathogens. Annu. Rev. Phytopathol. 40:309-348.

Williams, J. R., and Stelfox, D. 1980. Influence of farming practices in Alberta on germination and apothecium production of sclerotia of Sclerotinia sclerotiorum. Can. J. Plant Pathol. 2:169-172.

Wilson, M. 1996. An integrated biological control strategy for foliar bacterial diseases of tomato. IOBC Bull. 19:57.

Wilson, M. 1997. Biocontrol of aerial plant diseases in agriculture and horticulture: current approaches and future prospects. J. Ind. Microbiol. Biotechnol. 19:188-191.

Xiao, R. Y., Li, C. B., and Li, W. X. 2011. Study on the effect of K fertilizer and the balance of potash in a rice-rapeseed rotation system in southeast Hubei. Hubei Agric. Sci. 50:2190-2193.

Yin, Y., Liu, X., Shi, Z., and Ma, Z. 2010. A multiplex allele-specific PCR method for the detection of carbendazim-resistant Sclerotinia sclerotiorum. Pestic. Biochem. Physiol. 97:36-42.

Yu, Q., and Zhou, B. 1994. Integrated control of Sclerotinia disease in oilseed rape. Oil Crops China 16:8-10.

Zhang, R. 2002. Determination of filter paper enzyme activity and CMC enzyme activity of cellulose. Textile Aux. 19:51-53.

Zhao, J., and Meng, J. 2003. Detection of loci controlling seed glucosinolate content and their association with Sclerotinia resistance in Brassica napus. Plant Breed. 122:19-23.

Zhou, B. 1994. Resistance assessments of Sclerotinia disease in oilseed rape. Oil Crops China 16:88-94.

Zhou, T., and Boland, G. J. 1998. Biological control strategies for Sclerotinia diseases. Pages 127-156 in: Plant-Microbe Interactions and Biological Control. G. J. Boland and L. D. Kuykendall, eds. Marcel Dekker, New York. 